overexpressing melanopsin in blind retina

Amane Koizumi (1) ((I) National Institute for Physiological Sciences)

In this symposium, I will overview recent advances in the research of melanopsin, photosensitive biomolecular sensor in the retina. Melanopsin is an opsin-like protein found in the single population of retinal ganglion cells of mammals. Melanopsin is required for non-image-forming photic responses and contributes to entraining the mammalian circadian oscillator. Under the project led by Professor Masland (Harvard Medical School, Boston, USA), we have successfully restored vision in the blind mice by overexpressing melanopsin (OPN4) in retinal ganglion cells (Bin et al, PNAS 2008). In the study, after transfecting melanopsin into the retina of photoreceptor-degenerated blind mice, a large number of retinal ganglion cells expressed melanopsin and turned to be photosensitive. Whole-cell patch-clamp recording showed photoresponses in these cells even after degeneration of the photoreceptors. Several behabior tests revealed the recovery of photosensitivity in these blind mice. I will discuss further advances in melanopsin research.

3SP7-04 覚醒個体脳におけるホールセル記録と 2 光子イメージング

Whole-cell recording and two-photon imaging in awake animals

Kazuo Kitamura (1) ((I) The University of Tokyo)

Understanding how single neurons integrate the thousands of synaptic inputs they receive and thus contribute to computation in neural circuits in the intact brain is one of the most fundamental challenges in neuroscience. Addressing this issue requires recording synaptic input and manipulating spike output using intracellular recordings from identified single neurons in vivo, ideally in awake animals. The advent of whole-cell patch-clamp recordings in vivo has permitted low access-resistance intracellular recordings, which have provided important information regarding synaptic integration and the relationship of single neuron behavior to network function in various brain areas. However, since these recordings are made "blind", it is impossible to target recordings to specific neuronal types and specific regions of a cell. Also, there have been very limited observations in awake animals, mainly due to technical difficulties. We have overcome these problems by developing an approach for visualizing, identifying and making targeted patch-clamp recordings from single neurons in vivo. Neurons do not need to be fluorescently labeled prior to recording, instead, they are visualized as negative contrast images by perfusing the extracellular space with a fluorescent dye via the recording pipette. The same electrode is then placed on the neuron under visual control to allow gigaseal formation ('shadowpatching'). We demonstrate the reliability and versatility of shadowpatching by performing whole-cell recordings from visually identified neurons in neocortex and cerebellum of anesthetized rats and mice, also in awake mice. In the symposium, we will discuss our results as well as technical issues that one faces when making whole-cell recordings in awake animals.

\section{SP7-05 光刺激によるシナプス・ニューロン活動の誘発}

Optical stimulation of synapses and neurons

Masanori Matsuzaki (1) ((I) University of Tokyo)

We have developed novel photostimulation techniques for quantifying synaptic plasticity and manipulating neural activity in vivo. To address the structural basis of long-term potentiation, we developed two-photon photolysis of caged glutamate at single spines of hippocampal CA1 pyramidal neurons. Repetitive quantum-like uncaging of glutamate induced a rapid and selective enlargement of stimulated spines. Spine enlargement was associated with an increase in AMPA receptor-mediated currents at the stimulated synapse. In addition, when paired with postsynaptic spikes, two-photon uncaging of glutamate at single spines produced both immediate and gradual phases of spine enlargement. The gradual enlargement was strongly dependent on protein synthesis and brain-derived neurotrophic factor action. In addition, to permit rapid optical control of brain activity, we developed a method that uses Channelrhodopsin-2 (ChR2) for transcranial optogenetic stimulation. We applied this technique to the moto cortex of transgenic mice expressing ChR2 in cortical pyramidal cells Photostimulation induced limb movements that were time-locked with millisecond precision and could be induced at frequencies up to $20 \mathrm{~Hz}$. By scanning this light beam, we could map the distribution of neurons associated with limb movement. With this approach we could simultaneously define motor maps controlling two limbs and could reproducibly generate such cortical motor maps over periods of weeks.

\section{SP8-01 低線量率放射線照射マウス、植物体を用いた長期被ばく生物影響 研究}

Effects of long-term irradiation on mice or plants using low-dose rates

Tetsuo Nakajima (1) ((1) National Institute of Radiological Sciences)

The biological effects of low-dose radiation exposure, including health effects and environmental effects, are of public concern. Although molecular events in the cellular response to high-dose-rate radiation exposure have been fully investigated, effects of long-term exposure to low-dose-rate radiation remain unclear. Here, two experimental models, which can be performed using long-term, low-dose rates irradiation, are presented. One is a model using mice. Protein expression was analyzed by two-dimensional electrophoresis in livers from mice irradiated for 485 days at low-dose-rates of $0.04 \mathrm{mGy} /$ day, $0.86 \mathrm{mGy} /$ day and $17 \mathrm{mGy} /$ day (total doses of $0.02 \mathrm{~Gy}, 0.4 \mathrm{~Gy}$ and $8 \mathrm{~Gy}$, respectively). One of the proteins that showed marked changes in expression was identified as rhodanese (thiosulfate sulfurtransferase). Rhodanese is a detoxification enzyme, probably related to the regulation of antioxidative function. Its functions will be discussed with results of changes of antioxidative proteins, such as superoxide dismutase. Green soybean plants as another experimental model were used for evaluation of radiation effects on plants with low-dose-rates $(0.02 \mathrm{~Gy} / \mathrm{day}, 0.06 \mathrm{~Gy} / \mathrm{day}$ and $0.2 \mathrm{~Gy} / \mathrm{day})$ for 25 days. Though the gamma field, which is located in Hitachiohmiya, Ibaraki, has been usually used for breeding of plants, this facility is a convenient tool to irradiate plants for a long period. Effects on soybean plants will be presented and discussed in terms of appearance, productivity of peapod, and expressions of soybean seed proteins.

\section{SP8-02 線虫の神経機能に対する放射線影響とマイクロビーム照射実験の} 構想

Effects of ionizing radiation on the function of the nervous system in $C$. elegans and an attempt to locally targeted microbeam irradiation

Tetsuya Sakashita (1) ((1) Japan Atomic Energy Agency)

The microbeam irradiation study of a cultured cell has contributed to the development of the radiation-biology research, e.g. bystander effect. At present, the target-objects extend from a cultured cell into tissue or organ. We aim to study "in vivo" radiation effects using Caenorhabditis elegans (C. elegans). First, we investigated the broad-beam irradiation effects on the salt chemotaxis learning behavior. When $C$. elegans is exposed to the salt $(\mathrm{NaCl})$ and starvation simultaneously, the chemotaxis to $\mathrm{NaCl}$ is decreased. We found that the decrease of chemotaxis to $\mathrm{NaCl}$ during learning was enhanced by broad-beam (cobalt- 60 gamma rays) exposure, temporary. In addition, we demonstrated that ionizing radiation modulates the salt chemotaxis learning behavior via GPC-1 proteins localized in the specific sensory neurons. A radiation-sensitive site of the nervous system in C. elegans is postulated. Thus, we are planning the living target irradiation system of the heavy-ion microbeam, since the anesthetic method for fixation of $C$. elegans is not usable because the whole body irradiation affected only during the salt chemotaxis learning.

\section{SP8-03 プロトンマイクロビーム細胞照射装置 SPICE を用いた放射線影響} 研究

Biological studies using proton microbeam irradiation system, SPICE

Teruaki Konishi (1), Masakazu Oikawa (1), Hiroyuki Iso (1), Takahiro Ishikawa (1), Yuichi Higuchi (1), Kumiko Kodama (1), Mayu Isono (2), Nakahiro Yasuda (1), Noriyoshi Suya (1), Hitoshi Imaseki (1) ((I) National Institute of Radiological Sciences: (2) Tokyo Metropolitan University)

The development of SPICE (Single Particle Irradiation system to Cell), a microbeam irradiation system, has been completed at the National Institute of Radiological Sciences (NIRS). The beam size has been improved to approximately $2 \mu \mathrm{m}$ in diameter, and the cell targeting system can irradiate up to 400 cells per minute. Cell dish has been specially designed: a $2.5 \mu \mathrm{m}$ Mylar film stretched by pressing with a metal ring. A dish is placed on a voice coil stage equipped on the cell targeting system, which includes a fluorescent microscope and a CCD camera for capturing cell images. This microscope system captures images of dyed cell nuclei, computes the location coordinates of individual cells, and synchronizes this with the voice coil motor stage and single-particle irradiation system consisting of a scintillation counter and beam deflector. Irradiation of selected cells with a programmable number of protons is now automatable. We employed the simultaneous detection method for visualizing the position of mammalian cells and proton traversal through CR-39 to determine whether the targeted cells are actually irradiated. An Immuno-assay was also performed against $\gamma-\mathrm{H} 2 \mathrm{AX}$, to confirm the induction of DNA double-strand breaks in the target cells

\section{SP8-04 X線マイクロビームを用いた放射線誘発 DNA 損傷修復機構の解 析}

Repair process of radiation-induced DNA damage induced by X-ray microbeam

Masanori Tomita (1), Munetoshi Maeda (1), Noriko Usami (2), Katsumi Kobayashi (2) ((1) Central Research Institute of Electric Power Industry: (2) High Energy Accelerator Research Organization)

DNA double-strand breaks (DSBs) are one of the most lethal DNA lesions induced by ionizing radiations. There are at least two major DSB repair pathways, namely non-homologous end-joining (NHEJ) and homologous recombination 
(HR). In addition, the progression of DSB repair is closely related with cell cycle checkpoints. To analyze the response of DSB repair and cell cycle checkpoint proteins to radiation-induced DSBs, microbeam probes, which can induce DSBs in the targeted area of cell nuceli, are useful tools. In this study, we observed localization and phosphorylation of DSB repair and cell cycle checkpoint proteins in the microbeam-irradiated cell nuceli using synchrotron X-ray microbeam irradiation system (Photon Factory, KEK) and microbeam X-ray irradiation system (CRIEPI). Co-localization of phosphorylated histone H2AX at Ser139 ( $\gamma$-H2AX, generally known as a marker of DSBs) and DNA-PKcs (a senser of DSBs in NHEJ) at Thr2609 was observed in the nuclei of HeLa cells irradiated with microbeam. NBS1, 53BP1 and phosphorylated ATM at Ser1981, which are also suggested as the sensor of DSBs, were also co-localized with $\gamma$-H2AX. In the cells irradiated with high dose (30-60 Gy) of X-ray microbeam, colocalization of 53BP1 and $\gamma-\mathrm{H} 2 \mathrm{AX}$ was unresolved even $8 \mathrm{~h}$ after irradiation and diffused from irradiated area, suggesting the movement of damaged chromatin. Phosphorylated Chk2 and SMC1, which contribute to the control of $\mathrm{S} / \mathrm{G} 2$ checkpoint, are co-localized with $\gamma-\mathrm{H} 2 \mathrm{AX}$ in the irradiated part of cell nuclei. On the other hand, phosphorylated Chk1 observed entire irradiated cell nuclei. These results suggest that the response of DNA repair and cell cycle checkpoint proteins to DSBs varies in the each process of DNA repair and/or genome surveillance.

\section{SP8-05 放射光 X線を利用した最先端照射技術と放射線生物研究への応用}

The latest irradiation technique of synchrotron X-ray and its application to radiation biology

Katsumi Kobayashi (1), Noriko Usami (1), Munetoshi Maeda (2), Masanori Tomita (2) ((I) Photon Factory, IMSS, KEK: (2) Radiation Safety Research Center, Central Research Institute of Electric Power Industry)

Radiobiological processes begin with energy deposition events by photons and/or charged particles. The deposition events occur rather randomly, which causes difficulty to analyze the following reactions leading to biological phenomena. In order to investigate these processes analytically, we need to define the energy deposition events as much as possible, from energetic viewpoint and from spatial viewpoint. From energetic viewpoint, synchrotron radiation is an ideal light source, which has strong continuous spectrum from ultraviolet to X-ray region. Utilizing this characteristics, we have studied biological effects of inner shell photoabsorption of phosphorus in DNA molecules, and also of platinum which is artificially incorporated into cell. Inner shell photoabsorption is followed by Auger effects, which produce energy deposition events very densely around the photoabsorption site by Auger electrons. Since the cells have intracellular structures, local distribution of energy deposition events in the cell is very important in determining cellular response to radiation. We have recently developed a microbeam cell irradiation system utilizing the directionality of synchrotron X-rays. Minimum beam size available now is 2 micron, and using a developed software we can recognize and irradiate the target cells automatically. Another characteristics of the system is the ability to revisit the irradiated cells after various post-irradiation treatment. Using this system, we can now irradiate whole cell, or nucleus only, or cytoplasm only. Latest results will be presented.
1TA1-01 Conformation and Activity from Saturation Adsorptions of 1P-019 Lysozyme on the Surfaces of Nanosilica and Nanodiamond

Victor Wei-Keh Wu (1) ((1) Department of Chemical and Materials Engineering, National Kaohsiung University of Applied Sciences; Victor Basic Research Laboratory

Chicken egg white Lysozyme of $0-1000 \mathrm{nM}$ and suspension solutions of concentration $2.5 \mathrm{mg} / \mathrm{mL}$ of both nanoparticles (diameter $100 \mathrm{~nm}$ ) in PPBS of 7 $\mathrm{mM}$ at $\mathrm{pH}=11.0$ have been prepared. BET surfaces of 15 and $55 \mathrm{~m}^{2} / \mathrm{g}$ for nanosilica and -diamond, respectively, have been measured. Fluorescences from lysozyme before and after the adsorption on the surfaces of both nanoparticles have been measured. The adsorption thresholds at 175 and $190 \mathrm{nM}$, adsorption constants $1.2 \times 10^{7}$ and $6.5 \times 10^{7} \mathrm{nM}^{-1}$, and coverages for systems nanosilica and diamond, respectively, have been obtained. The load strength either 101 and 110 $\mathrm{mg} / \mathrm{g}$, or 1.8 and $2.0 \mathrm{mg} / \mathrm{m}^{2}$ as adsorbed lysozyme in $\mathrm{mg}$ by nanoparticle in $\mathrm{g}$, or on the surface of nanoparticle in $\mathrm{m}^{2}$ for nanosilica and -diamond, respectively, have been deduced. If the direct proportionality between coverage and activity of adsorbed lysozyme, and Zeta potential for system with nanodiaomond at $\mathrm{pH}=5$ are also valid for $\mathrm{pH}=11$, approximately $90 \%$ activity of as well as coverage by lysozyme at around $100 \mathrm{nM}$ can be deduced. However, loading or coverage with activity $90 \%$ can be achieved first of all at around $700 \mathrm{nM}$, if such proportionality can also be applied for nanosilica. Roughness and Zeta potential of the surface may be two of the factors, which influence the degree and kind of adsorption. It is possible, surface of nanodiamond is rougher than that of nanosilica. Therefore, more concentrated lysozyme solution is necessary for system nanosilica in order to achieve the comparable activity as with nanodiamond after adsorption. Helicity as well as activity of an adsorbed protein is one of the important criteria for efficient adsorption, even for application as carrier for optimal transfer. Ref.: V. W.-K. Wu, Chem. Lett. 2006, 1380; T.-T.-B. Nguyen, H.-C. Chang, and V. W.-K. Wu, Diamond and Rel.Materials, 2007, 16, 872.

1TA1-02 藍色細菌 Synechococcus sp. PCC 7942 の細胞内亜鉛イオン 1P-022＼cjkstart濃度センサー機能を持つ転写因子 SmtB の亜鉛イオン結合に伴 う構造変化に関する多次元 NMR 分光法による解析

Multidimensional NMR spectroscopic analysis with the structural changes of cyanobacterial transcription factor, $\mathrm{SmtB}$, functioning as the sensor for zinc-ion concentration in the cell, following zinc-ion binding

Hayato Morita (1), Hidenori Hayashi (2), Syunnosuke Abe (1), Takahisa Ikegami (3) ((I) Faculty of Agriculture, Ehime University: (2) Faculty of Science, Ehime University: (3) Institute for Protein Research, Osaka University)

In Synechococcus sp. PCC 7942, the smt locus is responsible for tolerance to divalent cations such as zinc and cadmium $\left(\mathrm{Zn}^{2+}\right.$ and $\left.\mathrm{Cd}^{2+}\right)$.Deletion of the smt locus induces a reduction of this $\mathrm{Zn}^{2+} / \mathrm{Cd}^{2+}$ tolerance. In the smt locus, there are two divergently transcribed genes, $s m t A$ and $s m t B$. The $s m t A$ gene encodes a class II metallothionein (56 amino acid residues), and the $s m t B$ one encodes a transacting repressor for smt A expression (122 amino acid residues).

In the absence of heavy metal ions, the transcription of smtA is repressed by the binding of $\mathrm{SmtB}$ to the operator/promoter region (about $100 \mathrm{bp}$ long) of $s m t A$ located between the $s m t A$ and $s m t B$ genes. The transcription of $s m t A$ is stimulated by trace amounts of heavy metal ions (especially $\mathrm{Zn}^{2+}$ and $\mathrm{Cd}^{2+}$ ). This stimulation is thought to be caused by inhibition of the complex formation between $\mathrm{SmtB}$ and the recognition DNA sequence, as a result of the binding of heavy metal ions to $\mathrm{SmtB}$. The relationship between the structural changes of $\mathrm{SmtB}$, induced by the metal-ion binding, and the consequent functional regulation of $\mathrm{SmtB}$ is still unclear. In our previous study, with the combination of genetic engineering and NMR spectroscopic techniques, we assigned the amino acid residues as the ligands for divalent metal ions in SmtB.

In this study, we have measured the $T_{1}, T_{2}$, and NOE relaxation NMR spectra of each amino acid constituting SmtB with/without zinc ions. We have found that in the N-terminal flexible region, flexibility around Cys14 which is one of the ligands for zinc ions is much decreased following zinc ion binding. This means that in the N-terminal region, the rigid structure around Cys 14 is induced by the zinc ion binding with $\mathrm{SmtB}$.

1TA1-03 ビスフェノールAとの相互作用はカルモジュリンのカルシウム結 $1 \mathrm{P}-028$ 合能を弱める

Bisphenol A weakens Calcium Binding Affinity of Calmodulin

Koichi Murayama (1), Tomoyoshi Terada (1), Masashi Sonoyama (2), Yasunori Yokoyama (3), Masayuki Nara (4), Yasuo Asami (5), Sadayuki Matsuda (6) (1) Graduate School of Medicine, Gifu University: (2) Graduate School of Engineering, Gunma University: (3) Graduate School of Engineering, Nagoya University: (4) College of Liberal Arts and Sciences, Tokyo Medical \& Dental University: (5) TA Instruments Japan Inc.: (6) School of Natural Science, Engineering and Agriculture, Hokkaido University of Education at Asahikawa)

Calcium plays critical roles in many cell functions as an intracellular second messenger. Calcium binding protein acts in a wide variety of biological phenomena. Calmodulin (CaM) is the most ubiquitous and important member of 